\title{
¿UN ACRÓSTICO (MÁS) EN VIRGILIO? (ENEIDA 10, 693-697) ${ }^{1}$
}

\section{GABRIELA ANDREA MARRON}

Universidad Nacional del Sur - CONICET

marron.gabriela@gmail.com

Recibido: 30/07/20

Aceptado: $20 / 08 / 20$

En una nota muy breve, publicada hace casi treinta años en Classical Quartely, Don FOWLER ${ }^{2}$ caracterizaba la recopilación de acrósticos accidentales en obras latinas realizada por Isidor HILBERG ${ }^{3}$, como firme candidata a recibir un premio en cualquier competencia de monumentos al trabajo desperdiciado. Sin embargo, también se detenía en uno de los ejemplos enumerados por HiLBERG y señalaba que, más allá del azar como posible factor, la afinidad temática entre ese acróstico y el contexto en que se inserta es notable. Se trata del comienzo del pasaje de la Eneida en que Virgilio describe la costumbre de abrir las puertas de la guerra. Tanto HILBERG como FOWLER citaban sólo los cuatro versos que forman el acróstico, pero recordemos el pasaje completo para apreciarlo mejor:

Mos erat Hesperio in Latio, quem protinus urbes

Albanae coluere sacrum, nunc maxima rerum

Roma colit, cum prima mouent in proelia Martem,

Siue Getis inferre manu lacrimabile bellum

Hyrcanisue Arabisue parant, seu tendere ad Indos

Auroramque sequi Parthosque reposcere signa.

sunt geminae Belli portae (sic nomine dicunt)

religione sacrae et saeui formidine Martis;

centum aerei claudunt uectes aeternaque ferri

robora, nec custos absistit limine lanus:

has, ubi certa sedet patribus sententia pugnae,

ipse Quirinali trabea cinctuque Gabino

insignis reserat stridentia limina consul,

ipse uocat pugnas; sequitur tum cetera pubes,

aereaque adsensu conspirant cornua rauco. (Verg. A. 7, 601-615) ${ }^{4}$ 
En el Lacio hesperio había una sagrada costumbre que las ciudades albanas llevaban adelante a través del culto; ahora la cultiva Roma, suprema grandeza de las cosas, cuando impulsan a Marte hacia los primeros combates, ya si para llevar la deplorable guerra con la tropa hacia los getas, los hircanos o los árabes se preparan, ya si para encaminarse a los indos y perseguir la Aurora y reclamarles enseñas a los partos. Hay dos puertas gemelas de la Guerra (así, con ese nombre, dicen) consagradas por la religión y por el formidable temor al cruel Marte. Cien palancas de bronce y la eterna robustez del hierro las cierran, y no se aleja del límite el vigilante Jano: a estas, cuando la certera sentencia del enfrentamiento se asienta entre los senadores, él mismo, con el cinto gabino y la trábea quirinal, les abre los estridentes límites como insigne cónsul, él mismo llama al enfrentamiento; lo sigue, entonces, la juventud restante, y conspiran con rauco consenso los broncíneos cuernos.

El contexto inmediato del acróstico está sembrado de indicios, orientados a percibir la presencia de Marte en el umbral (protinus, 601; nec absistit limine, 610; stridentia limina, 613) ${ }^{5}$, a observar los diversos signos (signa, 606; insignis, 613), y a relacionar el pasaje con la teoría atómica de Epicuro (maxima rerum, 602; prima mouent, 603) ${ }^{6}$. FOWLER finalizaba aquella breve nota de once líneas con una pregunta retórica y un comentario irónico, para descomprimir eventuales reparos en el campo disciplinar: "Dados los impecables precedentes helenísticos, ces inconcebible que Virgilio haya usado un acróstico de este modo? Aguardo a los hombres de bata blanca." "Si bien, transcurrido el tiempo, calificados aportes de diversos autores han contribuido a verificar que el acróstico de A. 7, 601-604 no es producto del azar $^{8}$, nos interesa indagar aquí su posible conexión con otro acróstico, que no parece haber sido señalado aún por la crítica9 ${ }^{9}$. Se trata del siguiente pasaje del libro diez de la Eneida, donde las letras iniciales de los versos 693-697 forman la palabra IOVIS:

at Iouis interea monitis Mezentius ardens

succedit pugnae Teucrosque inuadit ouantis;

concurrunt Tyrrhenae acies atque omnibus uni, uni odiisque uiro telisque frequentibus instant.

Ille, uelut rupes uastum quae prodit in aequor,

Obuia uentorum furiis expostaque ponto,

Vim cunctam atque minas perfert caelique marisque

Ipsa immota manens, prolem Dolichaonis Hebrum

Sternit humi, cum quo Latagum Palmumque fugacem, sed Latagum saxo atque ingenti fragmine montis occupat os faciemque aduersam, poplite Palmum succiso uolui segnem sinit, armaque Lauso donat habere umeris et uertice figere cristas. (Verg. A. 10, 689-701) 
Pero entretanto, por las admoniciones de Júpiter, Mezencio lo sucede ardiente en el combate y acomete a los triunfantes teucros. Convergen las columnas tirrenas y, con todos sus odios contra uno solo, contra uno solo con copiosos dardos, acosan al varón. Aquel -como la roca que sobresale en la vasta superficie del mar, colocada delante de las furias de los vientos y expuesta frente al ponto, que soporta toda la fuerza junta y las amenazas del cielo y del mar, quedando ella misma inmóvil- a Hebro, el hijo de Dolicáon, lo esparce contra el suelo, junto a Látago y al fugaz Palmo; pero de Látago, con una piedra y el ingente fragmento de un peñasco, se adelanta a cubrir la boca y el adverso semblante, mientras a Palmo, cortada la rodilla, lo deja revolcarse sin capacidad de respuesta. Las armas se las entrega a Lauso, para que las tenga en los hombros y fije el penacho en el vértice [del casco].

Además de la presencia del término Iouis al comienzo del pasaje y del sintagma uim cunctam, ensamblado en el hexámetro central del acróstico, la última palabra de los versos con los que se construye el nombre de Júpiter remite al agua que impacta en el símil sobre el flanco del peñasco: aequor, ponto, marisque, Hebrum ${ }^{10}$. Hay otras expresiones que funcionan como indicios: rupes prodit (693), obuia expostaque (694), uim cunctam perfert (695); también términos que aparecen dos veces, tanto inmediatamente antes, como después del acróstico: uni (691 y 692), Latagum (697 y 698), Palmum (697 y 699). Respecto a este último fenómeno, resulta sugerente la relación con el siguiente pasaje del poema de Lucrecio:

\author{
cum per inane meant uacuum nec res remoratur \\ ulla foris atque ipsa suis e partibus unum, \\ unum, in quem coepere, locum conixa feruntur, \\ debent ni mirum praecellere mobilitate (Lucr. 2, 158-161) ${ }^{11}$
}

Cuando [los átomos] circulan por el espacio vacío y no los retiene desde afuera ninguna cosa y a partir de sus partes ellos mismos son uno y uno es el lugar hacia donde comienzan [a moverse] e impetuosos son llevados, sin duda deben ir adelante por su movilidad.

Más allá de la relevante densidad etimológica de algunos términos incluidos en el pasaje virgiliano ${ }^{12}$, o de las distintas hipótesis que han intentado explicar el uso del sintagma louis monitis con relación a Mezencio ${ }^{13}$, uno de los aspectos más interesantes del acróstico IOVIS reside en que el símil homérico ${ }^{14}$ de la roca azotada por el oleaje remite a otra comparación. Es la que se le aplica al rey Latino, en los versos previos a la articulación del acróstico MARS del libro siete; con ella comparte ciertas reminiscencias léxicas, y en sus inmediaciones hay otros indicios de la inminente presencia de Marte en los bordes del texto.

Veamos el pasaje completo, a partir de la transición narrativa inicial, pero demorándonos brevemente en los segmentos previos al desarrollo del símil: 
nec minus interea extremam Saturnia bello

imponit regina manum. ruit omnis in urbem

pastorum ex acie numerus, caesosque reportant

Almonem puerum foedatique ora Galaesi

implorantque deos obtestanturque Latinum. (Verg. A. 7, 572-576)

Entretanto, la reina saturnia le da una mano no menos extrema a la guerra. Corre hacia la ciudad, desde la columna de pastores, todo el numeroso grupo. Traen de regreso a los caídos, al joven Almón y al semblante del desfigurado Galeso, e imploran a los dioses y ruegan a Latino.

En el primer verso, interea ocupa la misma posición métrica que en 10, 689, pero el sonido vocálico se atenúa por la sinalefa y suena como la preposición inter ${ }^{15}$. Galeso también es el nombre de un río de Calabria ${ }^{16}$. Y el sintagma preposicional, pastorum ex acie (574), prefigura las Thyrrenae acies $(10,691)$ del otro símil analizado.

Turnus adest medioque in crimine caedis et igni terrorem ingeminat: Teucros in regna uocari, stirpem admisceri Phrygiam, se limine pelli. (Verg. A. 7, 577-579)

Llega Turno y gemina el terror, en medio de señales de muerte y de fuego: los teucros son llamados al reino, se mezcla la estirpe frigia, él rebota contra el límite.

Aquí, el valor semántico de crimen (577) parece contextualmente próximo al de cerno ${ }^{17}$. Se menciona una vez más el borde (limine, 579). Ingeminat anticipa las puertas gemelas del verso 605 . Y el infinitivo pasivo pelli se vincula con el nombre de Palmo ${ }^{18}$.

tum quorum attonitae Baccho nemora auia matres insultant thiasis (neque enim leue nomen Amatae), undique collecti coeunt Martemque fatigant. ilicet infandum cuncti contra omina bellum, contra fata deum peruerso numine poscunt. (Verg. A. 7, 580-584)

Entonces aquellos -cuyas madres, aturdidas por Baco, saltan en cortejos por lejanos bosques (pues no es leve el nombre de Amata)- desde todas partes, unidos entre sí, se aglutinan y erosionan a Marte. Y de inmediato, contra los signos, contra las palabras de los dioses, piden juntos la infanda guerra, con numen adverso. 
Marte (infandum bellum, 583; peruerso numine, 584) se encuentra rodeado por términos que evocan la fusión de los habitantes del Lacio para desgastarlo: collecti... coeunt... (582), cuncti... fatigant (582). Una vez más, hay señales que advierten: omina (583). A su vez, el nomen (comen?) de Amata conecta fónicamente el pasaje con otro silencioso umbral, en el que se sienta la furia Alecto, cuando la reina es mencionada por primera vez en el poema: tacitumque obsedit limen Amatae (Verg. A. 7, 343) ${ }^{19}$. Por último, a la repetición de contra, que tiene lugar en los versos 583 y 584, se suma la de pelagi rupes (586 y 587) y circum (588 y 589), ya dentro del símil:

certatim regis circumstant tecta Latini;

ille uelut pelagi rupes immota resistit, ut pelagi rupes magno ueniente fragore, quae sese multis circum latrantibus undis mole tenet; scopuli nequiquam et spumea circum saxa fremunt laterique inlisa refunditur alga. (Verg. A. 7, 585-590)

A porfía, rodean la cubierta morada de rey Latino. Aquel resiste inmóvil, como la roca del piélago, como la roca del piélago cuando un magno fragor sobreviene, cuando se sostiene en su mole, entre múltiples olas que ladran $\underline{a}$ su alrededor; a su alrededor rugen en vano las espumosas piedras y los escollos, y otra vez se dispersan las algas estrelladas en su costado.

El léxico destacado en negrita anticipa la presencia de los mismos términos en torno al acróstico que bordea el símil del libro diez. Como ya hemos señalado, en los versos con los que se forma allí el nombre de Júpiter, la última palabra de cada hexámetro remite al agua; aquí, pese a que las olas también están presentes (undis, 588) ${ }^{20}$, se privilegian en cambio las indicaciones espaciales (circumstant, 585; lateri, 590) y los indicios sonoros (fragore, 587; latrantibus, 588; fremunt, 590), acaso orientados a reforzar no sólo la percepción del acróstico cercano, sino también la del más distante.

El principal propósito de esta breve nota ha sido señalar la existencia material del acróstico IOVIS en A. 10, 693-697. Simultáneamente, procuramos identificar algunas de las pistas que contribuyen a detectarlo e indagar sus posibles vínculos con el pasaje en que se inserta el acróstico MARS (A. 7, 601-604); no obstante, las líneas de lectura planteadas constituyen meramente una invitación al diálogo ${ }^{21}$. 


\section{Bibliografía}

ADKIN, N. (2007). The Etymology of segnis in Vergil. AC, 76, 171-176.

AHL, F. (1985). Metaformations. Soundplay and Wordplay in Ovid and other Classical Poets. Ithaca-London.

AHL, F. (2007). Virgil. Aeneid. A New Translation. Oxford-New York.

Basson, W. P. (1984). Vergil's Mezentius: A Pivotal Personality. Acta Classica, 27, 57-70.

BuRKE, P. (1974). The Role of Mezentius in the Aeneid. CJ, 69, 202-209.

Conte, G. B. (2019). P. Vergilius Maro Aeneis. Berlin-Boston, [2009].

CouRTNEY, E. (1990). Greek and Latin Akrostics. Philologus, 134, 3-13.

EISENHUT, W. (1983). Catulli Veronensis Liber. Leipzig.

FeENEY, D. \& NeLIS, D. (2005). Two Virgilian Acrostics: certissima signa? CQ, 55, 644-646.

FLORIO, R. (2020). Lucrecio, Átomos y Letras, Borges. Memoria, arte combinatorio y asociación. En La Fico Guzzo, M. L. et al. (Eds.), La retórica heroica: construcción y reformulación a través de la épica y la tragedia [en prensa]. Bahía Blanca.

FOWLER, D. (1983). An acrostic in Vergil (Aeneid 7. 601-4)? CQ, 33(1), 298.

GLENN, J. (1972). Homer’s 'God-Trusting' Cyclopes. CW, 65, 218-220.

GRISHIN, A. (2008). Ludus in undis: An acrostic in Eclogue 9. HSCP, 104, 237-240.

HANSES, M. (2016). Love's Letters: an Amor-Roma Telestich at Ovid, Ars Amatoria 3.50710. En Mitsis, P. \& Ziogas, I. (Eds.), Wordplay an Powerplay in Latin Poetry (pp. 199211). Berlin-Boston.

HARRISON, S. (1991). Vergil, Aeneid 10: With Introduction, Translation, and Commentary. Oxford.

Hendry, M. (1994). A Martial Acronym in Ennius? Liverpool C. Monthly, 19, 109-109.

HILBERG, I. (1899). Ist die Ilias Latina von einem Italicus verfasst oder einem Italicus gewidmet? WS, 21, 264-305.

HILBERG, I. (1900). Nachtrag zur Abhandlung 'Ist die Ilias Latina von einem Italicus verfasst oder einem Italicus gewidmet?'. WS, 22, 317-318.

HINDS, S. (2006). Venus, Varro and the vates: Towards the Limits of Etymologizing Interpretation. Dictynna, 3, 1-19.

HorSFALl, N. (2000). Virgil: Aeneid 7. A commentary. Leiden.

KATZ, J. T. (2013). The Muse at Play: An Introduction. En Kwapisz, J. et al. (Eds.), The Muse at Play. Riddles and Wordplay in Greek and Latin Poetry (pp. 1-30). Berlin-Boston.

MARTIN, J. (1969). T. Lucretius Carus. De Rerum Natura. Leipzig.

MORGAN, G. (1993). Nullam, Vare... Chance or choice in Odes 1.18? Philologus, 137, 142145.

Paschalis, M. (1997). Virgil's Aeneid: Semantic Relations and Proper Names. Oxford.

PERI Rossi, C. (1983). El museo de los esfuerzos inútiles. Barcelona.

Perutelli, A. (1972). Similitudini e stile ‘soggettivo' in Virgilio. Maia, 24, 42-60. 
Perutelli, A. (1995). Vergil, Aeneid 10. With Introduction, Translation and Commentary by S. J. Harrison. Oxford: Clarendon Press, 1991. (Reseña). Gnomon, 67, 311-315.

RoBINSON, M. (2019a). Arms and a Mouse: Thinking about acrostics in Vergil and Ovid. MD, 82, 23-73.

RoBINSON, M. (2019b). Looking Edgeways. Pursuing Acrostics in Ovid and Virgil. CQ, 69, 1-19.

QuinN, K. (1968). Virgil's Aeneid: A Critical Description. London.

SCHMID, W. (1983). Vergil-Probleme. Güppingen.

SNyder, J. M. (1980). Puns and Poetry in Lucretius De Rerum Natura. Amsterdam.

WILLS, J. (1996). Repetition in Latin Poetry. Figures of Allusion. Oxford.

ZIOGAS, I. (2016). Introduction: Power, Puns and Politics From Horace to Silius Italicus. En Mitsis, P. E Ziogas, I. (Eds.), Wordplay an Powerplay in Latin Poetry (pp. 1-12). BerlinBoston.

Notas

${ }^{1}$ Este trabajo forma parte de proyectos de investigación financiados por por la ANPCyT (PICT 2016 No 1012), por la SGCyT de la UNS (PGI 24/I 271), y por la SGCyT de la UNNE (PI 17H014). Agradezco al Dr. Rubén Florio la atenta lectura de la versión preliminar de esta nota y sus pertinentes sugerencias.

2 FOWLER (1983).

${ }^{3}$ Cf. Hilberg $(1899,1900)$.

${ }^{4}$ Cito por la edición de CONTE (2019); todas las traducciones incluidas en la nota son de mi autoría.

${ }^{5}$ Acaso el término Indos también sea un indicio, cf. Catul. 11, 1-6: Furi et Aureli, comites Catulli, / siue in extremos penetrabit Indos, / litus ut longe resonante Eoa / tunditur unda, / siue in Hyrcanos Arabasue molles / seu Sacas sagittiferosue Parthos / [gradietur] ("Furio y Aurelio, compañeros de Catulo, ya si ha de internarse en los indos extremos, donde la orilla es azotada por la resonante ola de la Aurora, ya si ha de avanzar contra los hircanos o los delicados árabes o los sagas o los flechadores partos"); cito por la edición de EISENHUT (1983).

${ }^{6}$ Cf. por ejemplo, Lucr. 2, 1007-1022; respecto a la analogía entre las letras y los átomos en el De Rerum Natura. Cf. SNYDER (1980, p. 31-51) y FLORIO (2020).

${ }^{7}$ FOWLER (1983:298): "Given the impeccable Hellenistic precedents, is it inconceivable that Vergil should have used an acrostic in this way? I await the men in white coats".

${ }^{8}$ Cf. SCHMID (1983, p. 338); COURTNEY (1990: 11): "The achrostich MARS at Verg. A. 7. 601-4, lines wich describe a rite of the Romans cum prima mouent in proelia Martem (603), [...] comes at [...] the beginning of a new paragraph and an important turning-point in the narrative"; MORGAN (1993, p. 143): "There is no hesitation if the context is clear and (if 
possible) it contains a referent word that points the message of the acrostic. [...] And can we really hesitate when Vergil writes (Aeneid 7.601-604)?"; HENDRY (1994, p. 108): "the word Mars is spelled out by the first letters of the first four words of Ennius' most quoted line (Annales 156 Skutsch = 500 Vahlen): Moribus Antiquis Res Stat Romana uirisque. Ennius is not Vergil and an acronym is not an acrostic, but the similarities are nevertheless striking: not only is the word spelled out the same as in Aeneid 7.601-4, the first of the 'background' words is again a form of mos"; HORSFALL (2000, p. 391): "Like it or not, this was an old Alexandrian game and however serious the passage, such an ornamentation is truly not grotesque"; FEENEY \& NELIS (2005, p. 644): "The reader's attention should be drawn to the existence of Mars in the acrostic by the words prima mouent... Martem. This signal may be compared with the better known technique of marking particularly allusive passages by employing the vocabulary of memory or echo, a practice which is itself closely related to the ways in which Virgil marks his use of particular Homeric passages and broader narrative structures"; y HANSES (2016, p. 207-208). Las referencias brindadas no son exhaustivas, ya que este es, como sostiene GRISHIN (2008, p. 237), "perhaps the most celebrated acrostic in Virgil"; prueba de ello es, por ejemplo, su recuperación a través de las letras iniciales de esos versos en la traducción inglesa de la Eneida realizada por AHL (2007: 177).

${ }^{9}$ Cf. KATZ (2013, p. 6) y Robinson (2019a, 2019b); tampoco Hilberg $(1899,1900)$ lo incluye en sus listados.

${ }^{10}$ Río de Tracia, mencionado también en Verg. A. 1, 317; cf. PASCHALIS (1997, p. 339): "As a river-name it combines with the water element of the rock simile."

${ }^{11}$ Cito por la ed. de MARTIN (1969); cf. la nota 6, y también WILLS (1996, p. 132): “The Lucretian image of swift atoms striving together towards a single point aptly fits the Etruscan rushing together against the sole Mezentius. The difficulty of the Lucretian passage would have made it memorable for Virgil in a technical way. Although Munro emended the first unum to una, if my connection is right, it supports the reading of unum. Virgil's instant may not be accidental, cf. Lucr. 5.298-9."

${ }^{12}$ Cf. PASCHALIS (1997, p. 339): “The huge 'fragment' (fragmine) of a mountain he throws at Latagus evokes the ancient etymology of rupes from rumpo. [...] [Palmus'] name suggest $\pi \alpha \lambda \mu$ ó ('pulsation', 'throbbing'; 'palpitation of the heart'; 'a rapid motion'), a derivative of

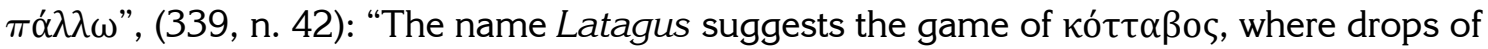
wine ( $\lambda \alpha \alpha \tau \gamma \varepsilon \varsigma)$ remaining in the cup were thrown into a basin with a splash"; ADKIN (2007, p. 173): "The reason for Virgil's somewhat surprising choice of segnis to describe Palmus would seem to have been the desire to draw an etymologizing contrast (se igni) with the ardens that qualifies his enemy Mezentius at the very start of his aristeia ten lines earlier, where this participle stands in emphatically final position"; lo señalado por AHL (1985, p. 144-145) respecto a Iouis y uis en las Metamorfosis, por HINDS (2006, p. 5-9) sobre Venus y uis en Varrón, y por ZIOGAS (2016, p. 1-3) acerca de Iouis y uis en los Fastos.

${ }^{13}$ Cf. por ejemplo, QuINN (1968, p. 229): "The phrase Iouis monitis looks like a casual formula (it is used of Aeneas at 4.331, like a formula of Tarchon at 11.727-8); we may feel that Virgil has nodded -forgotten that Mezentius is the last man to listen the promptings of Jove. Virgil of course has not forgotten. He wants to make the point that even this rabid atheist (7.648: contemptor diuum, cf. 8.7) is under Jove's control"; GLENN (1972, p. 220): "Rather, we may rightly infer that the pious attitude is that of the poet, who is describing the warrior's actions in terms of the will of Jupiter"; BURKE (1974, p. 205-206): "Light may be shed upon the apparently anomalous application of the phrase Iouis... monitis to Virgil's 
contemptor diuum by observing the similarity of these lines to Iliad 15. 592-604, where the Trojans are inspired by Zeus to attack the Greeks. Lines 689-690 recall the passage in Iliad 15 and introduce the series of Homeric battle-scenes which immediately follows. Only by realizing that Jupiter in Aeneid 10. 689 is in fact a transformation of Homer's Zeus, and not really the same Jupiter we encountered in the concilium deorum at the beginning of book 10 , can we reconcile the contradictory actions and words of the god who at 10. 107-113 declares that he will be absolutely impartial in the coming battles, and who at 10.689 actively influences the fighting. Virgil has not simply transformed his Homeric model, but has used the model to give an ironic flavor to the passage transformed"; y la síntesis de Basson (1984, p. 60-61).

${ }^{14}$ Cf. Hom. Il. 15, 618-62; y la interpretación de BURKE (1974, p. 205-206), citada en la nota 13. En Macr. 6, 3, se propone una relación entre la comparación de Verg. A. 7, 586-590 y la de Hom. Il. 16, 102-111, pero a través de Enn. Ann. 15, 391-398. Sobre el símil del libro 7, cf. HARRISON (1991, p. 237), y PERUTELLI (1972, p. 57-58 y 1995, p. 312-313); sobre símil el del libro 10, cf. HORSFALL (2000, p. 381-328).

${ }^{15}$ Respecto a extremam... manum, cf. lo señalado en la nota 5 acerca de extremos... Indos.

${ }^{16}$ Cf. PASCHALIS (1997, p. 264), y la nota 10 sobre Hebrum.

${ }^{17}$ Respecto a la oscuridad de la construcción, cf. HORSFALL (2000, p. 378).

${ }^{18} \mathrm{Cf}$. lo señalado en la nota12, y también Epicur. Ep. 43, donde $\pi \alpha \lambda \mu$ ó refiere a la incesante palpitación de los átomos, y à $\pi 0 \pi \alpha \lambda \mu$ ó a la vibración que experimentan al colisionar entre sí y rebotar. Turno no integraría la amalgama del nuevo cuerpo social fusionado en el Lacio. A través del otro símil, el poeta parece expresar que tampoco habrá posibilidad alguna de compenetración entre Mezencio y la nueva coalición de pueblos. Nótese, a su vez, que los pastores latinos que se enfrentan primero a los troyanos son una mera sumatoria de "partes", cf. Verg. A. 7, 624-626: pars... pars... / omnes... / pars...

${ }^{19}$ Cf. PASCHALIS (1997: 255): "These clusters suggest an etymological association of the name Amata with amor. The epithet tacitum applied to the limen of Amata's chamber suggests secret thoughts [...]; the place is Latium (<lateo), where passion 'lurks' before it erupts violently, and specifically the tecta of Latinus (properly the past participle of tego, 'cover', 'hide', 'conceal')."

${ }^{20}$ Cf. GRISHIN (2008), donde se señala la presencia del acróstico VNDIS en Verg. Ecl. 9, 3438.

${ }^{21}$ En tal sentido, coincidimos con ROBINSON (2019b, p. 2): "My approach is (...) to assume that the ancient 'learned reader' was also in the habit of reading texts in pursuit of acrostics, and was sensitive to them."

22 Debo la referencia a El Museo de los Esfuerzos Inútiles (PERI RossI, 1983, p. 7), libro publicado algunos meses antes de que FOWLER (1983, p. 298) concediera a la recopilación de acrósticos accidentales de HILBERG $(1899,1900)$ un lugar destacado entre aquellos "monuments of wasted labour." 